\title{
Analysis of fiscal decentralization impact on community welfare in Jambi Province
}

\author{
M. Zahari. MS ${ }^{1 *}$; Syamsurijal Tan²; Haryadi²; Syaparuddin ${ }^{2}$ \\ ${ }^{1}$ Faculty of Economics, Universitas Batanghari, Indonesia \\ ${ }^{2}$ Faculty of Economics and Business, Universitas Jambi, Indonesia \\ *Towhom correspondence should be addressed.Email: zaharisahar@yahoo.com
}

\begin{abstract}
The fiscal decentralization policy has made local governments have the authority to generate income and manage regional finance independently for public services and public welfare. This study aims to: 1) Analyze the degree of fiscal decentralization in Jambi Province; 2) Analyzing community welfare proxied from the human development index in Jambi Province; 3) Analyzing the impact of fiscal decentralization on the welfare of the community in Jambi Province. This study using panel data, a combination of time series data in 2010-2016 and cross section 11 districts/cities in Jambi Province. The method of data analysis is descriptive analysis and panel data regression analysis approach, namely the fixed effect model (FEM). Hypothesis testing uses the F test statistic and the statistical $t$ test. The results showed that: 1) The degree of fiscal decentralization, namely the ratio of district own source revenue (PAD) to total regional income (TPD) in each district/city in Jambi Province was relatively relatively low, whereas for Jambi Province it was in good category; 2) Community welfare as illustrated by the human development index in each district/city including Jambi Province is still in the moderate category, except Jambi City (76.14) and Sungai Penuh City (73.35) are categorized as high; 3) Fiscal decentralization has a positive and significant impact on improving community welfare. it means that the better the implementation of fiscal decentralization, the higher the level of community welfare.
\end{abstract}

Keywords: Community welfare, District own source revenue, Fiscal decentralization, Human Development Index

JEL Classification: H30, H50, H72

\section{INTRODUCTION}

Human development is one indicator that assesses the success of development to improve the welfare and intellectual life of the nation. The United Nations Development Program (UNDP), through its Human Development Report, stated that human development is "a process of enlarging people 'choices" or a process that enhances aspects of people's lives (Harahap, 2011). In principle, human choices are very numerous and change at any time. But at all levels of development, there are three basic choices, namely to live long and live a healthy life, to get education and to have access to the necessary resources to live a decent life (BPS, 2016).

At present the use of the Human Development Index (HDI) as a welfare indicator can be widely accepted throughout the world, even at the regional level (Bappenas, 2011). Giving regional autonomy through fiscal decentralization and regional authority is expected to provide flexibility to the regions to improve the welfare of the community 
(Harahap, 2011). The study of Lindaman and Thurmaier (2002) found that fiscal decentralization has a positive effect on people's welfare (achieving basic needs for society). Soejoto, et.al. (2015), stated that fiscal decentralization policies play an important role in supporting the success of Indonesian human development. Mirza (2012), in implementing fiscal decentralization, improving the quality of human life can be seen from the Human Development Index (HDI) which is measured through the quality of education, health and economic levels (purchasing power).

The development of HDI in various regions in Jambi Province in the period 20102016 showed an increase, from 65.39 in 2010 to 69.62 in 2016. During this period, the HDI of Jambi Province grew by an average of 1.05 percent per year. The increase in the Jambi Province HDI, of course, was accompanied by an increase in HDI in each district/city in Jambi Province. In 2016, the highest district/city HDI was in Jambi City, namely 76.14 , followed by Kota Sungai Penuh at 73.35 and Kerinci Regency at 69.68, while the lowest HDI was in Tanjung Jabung Timur Regency at 61.88 , followed by Tanjung Jabung Barat District at 65.91 and Muaro Jambi District at 67.55. In detail, look at the following table:

Table 1. HDI district/city and Province of Jambi, Year 2010 - 2016

\begin{tabular}{|c|c|c|c|c|c|c|c|c|}
\hline \multirow{2}{*}{ No. } & \multirow{2}{*}{ Region } & \multicolumn{7}{|c|}{ Human Development Index } \\
\hline & & 2010 & 2011 & 2012 & 2013 & 2014 & 2015 & 2016 \\
\hline 1. & Kerinci & 65.16 & 65.9 & 66.7 & 67.5 & 67.96 & 68.89 & 69.68 \\
\hline 2. & Merangin & 63.85 & 64.4 & 65.3 & 65.8 & 66.21 & 67.4 & 67.86 \\
\hline 3. & Sarolangun & 64.64 & 65.2 & 66.2 & 67.1 & 67.67 & 68.1 & 68.73 \\
\hline 4. & Batanghari & 65.67 & 66.3 & 67.0 & 67.2 & 67.68 & 68.05 & 68.7 \\
\hline 5. & Muaro Jambi & 62.84 & 63.4 & 64.2 & 65.1 & 65.71 & 66.66 & 67.55 \\
\hline 6. & Tanjung Jabung Timur & 57.21 & 57.8 & 58.6 & 59.4 & 59.88 & 61.12 & 61.88 \\
\hline 7. & Tanjung Jabung Barat & 61.49 & 62.0 & 62.9 & 63.5 & 64.04 & 65.03 & 65.91 \\
\hline 8. & Tebo & 63.62 & 64.5 & 65.2 & 65.9 & 66.63 & 67.29 & 68.05 \\
\hline 9. & Bungo & 66.28 & 66.7 & 67.2 & 67.5 & 67.93 & 68.34 & 68.77 \\
\hline 10. & City of Jambi & 72.23 & 73.0 & 73.8 & 74.2 & 74.86 & 75.58 & 76.14 \\
\hline \multirow[t]{2}{*}{11.} & City of Sungai Penuh & 69.91 & 70.6 & 71.2 & 72.1 & 72.48 & 73.03 & 73.35 \\
\hline & Jambi Province & 65.39 & 66.1 & 66.9 & 67.8 & 68.24 & 68.69 & 69.62 \\
\hline
\end{tabular}

Source: BPS of Jambi Province, HDI, 2010 - 2016

The description of this HDI shows the need for hard work of all Regional Government apparatus, both districts / cities and provinces to try to improve the HDI through improving regional economic performance, quality of education, and access to public health services. To be able to realize an increase in HDI in order to improve the welfare of the community, of course it must be supported by adequate regional financial capacity, especially the provision of funds sourced from the region's own revenues. The improvement in regional revenues will contribute to increasing the quality of people's welfare as measured by the HDI. More and more income is generated by the region, making the region able to finance and meet the needs expected by the community (Christy and Adi, 2009).

One of the most important sources of regional revenue in the implementation of decentralization (regional autonomy) is District own source revenue (PAD). The size of the PAD can increase or reduce dependence on the central government (Setyowati and Suparwati, 2012). The increase in PAD is certainly supported by efforts to extract local tax sources, regional retribution, business proceeds and regional wealth as well as other legitimate PAD. The ratio of PAD to total regional income illustrates the degree of fiscal decentralization or financial independence of a region. 
Based on Table 2, the realization of PAD shows an increase, which in 2010 amounted to Rp.686 billion and in 2016 became Rp. 1,273 billion or grew by an average of 11.89 percent per year. This increase in PAD has not been fully reliable in supporting the Regional Government Budget (APBD) of Jambi Province, because the contribution of PAD to the Regional Government Budget is relatively low and tends to decrease. In 2010, PAD contributed 37.26 percent, in 2011 it increased to 40.46 percent, and in 2016 PAD was only able to contribute to the Jambi Province's APBD of 34.02 percent or a decrease of 6.44 percent compared to the realization of the annual budget 2011. This condition certainly causes a high dependency on funds from the central government, because the ratio of balancing funds to the Jambi Provincial Budget even though the trend tends to show a decline but until 2016 the ratio of balance funds (41.39 percent) still exceeded the PAD ratio. In detail the description of the ratio of PAD and balancing funds to the Jambi Provincial Budget can be seen in Table 2 below:

Table 2. Contribution of PAD and balancing fund to APBD of Jambi Province, Year 2010-2016

\begin{tabular}{cccccc}
\hline YEAR & $\begin{array}{c}\text { PAD } \\
\text { (Rp.Billion) }\end{array}$ & $\begin{array}{c}\text { Fund Balance } \\
\text { (Rp. Billion) }\end{array}$ & $\begin{array}{c}\text { APBD } \\
\text { (Rp.Billion) }\end{array}$ & $\begin{array}{c}\text { Ratio (\%) } \\
\text { PAD/APBD }\end{array}$ & $\begin{array}{c}\text { Ratio (\%) } \\
\text { DP/APBD }\end{array}$ \\
\hline 2010 & 686 & 932 & 1.841 & 37,26 & 50,62 \\
2011 & 984 & 1.075 & 2.432 & 40,46 & 44,20 \\
2012 & 995 & 1.332 & 3.287 & 30,27 & 40,52 \\
2013 & 1.063 & 1.489 & 3.577 & 29,72 & 41,63 \\
2014 & 1.281 & 1.514 & 3.679 & 34,82 & 41,15 \\
2015 & 1.241 & 1.419 & 3.604 & 34,43 & 39,37 \\
2016 & 1.273 & 1.549 & 3.742 & 34,02 & 41,39 \\
\hline
\end{tabular}

Source: BPS of Jambi Province, Regional Financial Statistics, 2010 - 2016

Considering the different conditions and potentials of each region, the consequences of differences in ability to mobilize development activities and explore the potential of existing regions can cause various problems in the implementation of fiscal decentralization in each region, especially regarding the problem of managing resources regional finance, in order to increase regional independence and human development in order to improve people's welfare.

Based on the problems described, this study aims to: Analyzing the degree of fiscal decentralization in Jambi Province, analyzing community welfare proxied from the human development index in Jambi Province, and analyzing the impact of fiscal decentralization on the welfare of the community in Jambi Province.

\section{LITERATURE REVIEW}

\section{Concept of community welfare}

Welfare is the dream of every person and every society, even every country. The prosperous conditions of community and state life are idealized (Soetomo, 2014). Welfare by some people is always associated with the concept of quality of life. The concept of quality of life is a picture of a good state of life. The World Health Organization (WHO) defines quality of life as an individual's perception of life in society in the context of existing cultural and value systems related to goals, expectations, standards, and also attention to life. This concept provides broader meaning because it is influenced by the physical condition of the individual, psychological, level of independence, and individual social relations with the environment. In the context of statehood, welfare is used in order to show that his government provides broad social services to its citizens (Fahrudin, 2012).

According to Todaro and Smith (2015), community welfare shows a measure of community development outcomes in achieving a better life which includes: first, 
capacity building and distribution of basic needs such as food, housing, health, and protection; second, increase in living levels, income levels, better education, and increased attention to culture and human values; and third, expanding the scale of the economy and the availability of social choices from individuals and nations.

The Human Development Index (HDI) is a tool used to measure welfare levels between countries or between regions (Todaro and Smith, 2006). Priambodo and Noor (2016), emphasizing the achievement of community welfare can be calculated one of them by the Human Development Index (HDI).

Starting in 1990 the United Nations Development Program (UNDP) published public welfare indicators known as the Human Development Index (HDI). In 2010, UNDP made changes in the preparation of the HDI indicator, namely on the dimensions of education and living standards. The indicator of literacy rates in the education dimension is replaced by the expectations of school length, while the indicator of GDP per capita in the dimensions of living standards is replaced by an indicator of gross national income (GNI) per capita. The HDI aggregation method undergoes improvements, health indexes and expenditure indexes from arithmetic averages to be geometric averages. Likewise, the education index changes from a geometric average to an arithmetic average. The calculation of these three indices is done by standardizing the minimum and maximum values of each index component. Each of these components is first calculated so that the value is between 0 (worst) and 1 (best). To facilitate the analysis, this index is usually multiplied by 100 .

Indonesia began applying the HDI calculation with the new method in 2014. In general, the method of calculating the HDI used in Indonesia is the same as the calculation method used by UNDP. The formula used in calculating the HDI component index is as follows (BPS, 2017):

\section{Health Index}

$$
\mathrm{I}_{\text {health }}=\frac{\mathrm{AHH}_{0}-\mathrm{AHH}_{0 \text { min }}}{\mathrm{AHH}_{0 \text { max }}-\mathrm{AHH}_{0 \text { min }}}
$$

\section{Education Index}

$$
\begin{aligned}
& \mathrm{I}_{\mathrm{HLS}}=\frac{\mathrm{HLS}-\mathrm{HLS}_{\min }}{H L S_{\max }-H L S_{\min }} \\
& \mathrm{I}_{\mathrm{RLS}}=\frac{\mathrm{RLS}-\mathrm{RLS} S_{\min }}{R L S_{\max }-\mathrm{RLS}_{\min }} \\
& \mathrm{I}_{\text {Education }}=\frac{\mathrm{I}_{\mathrm{RLS}}-\mathrm{I}_{\mathrm{HLS}}}{2}
\end{aligned}
$$

Table 3. Components of HDI

\begin{tabular}{llcc}
\hline \multicolumn{1}{c}{ Component } & Unit & Min & Max \\
\hline Life Expectancy at Birth $\left(\mathrm{AHH}_{0}\right)$ & Year & 20 & 85 \\
School Old Hope (HLS) & Year & 0 & 18 \\
Average School Length (RLS) & Year & 0 & 15 \\
Per capita expenditure adjusted & Rupiah & 1.007 .436 & 26.572 .352 \\
\hline
\end{tabular}

Source: BPS, 2017

The value of HDI can be calculated using the following formula:

$$
\mathrm{IPM}=\sqrt[3]{\mathrm{I}_{\text {health }} \mathrm{XI}_{\text {education }} \mathrm{XI}_{\text {expenditure }}}
$$


Where:

IHealth = life expectancy index

IEducation = education index (school expectation index + school mean index divided by 2)

Iexpenditure $=$ Index Standard of decent living (expenditure value per capita and purchasing power parity).

Furthermore, BPS (2017) explains to see the achievements of human development in a region at a certain time can be grouped into four groups, ie low HDI (HDI <60), medium $(60 \leq \mathrm{HDI}<70)$, high $(70 \leq \mathrm{HDI}<80)$, and very high $(\mathrm{HDI} \geq 80)$.

\section{Fiscal Decentralization}

The terminology of decentralization does not only have one meaning. But it can be translated into a number of meanings, depending on the context of their use. According to Kuncoro (2014) decentralization is the delegation of authority and responsibility (for public functions) from the central government to local governments. Slinko (2002) states that in the concept of "fiscal decentralization" it means the assignment of fiscal responsibility to lower levels of government, namely, the level of regional autonomy (local) and the authority of local governments to decide on their own expansion and their ability to generate local income.

Bodman et.al. (2009) states that theoretically fiscal decentralization is a devolution of fiscal responsibility and power from the central government to regional governments that can increase or reduce economic growth. The main function of fiscal decentralization is to increase the efficiency of the public sector and lead to long-term economic growth (Faridi, 2011).

Fiscal decentralization is measured using three approaches, namely the income approach, expenditure approach, and local revenue approach (Akai and Sakata, 2002; Iimi, 2005).

a. Approach to Acceptance.

The indicator of fiscal decentralization from this approach is measured by the provincial revenue ratio. Indicator of Revenue (RI) is the ratio of regional government revenues to central and regional government revenues. The receipt of local government used in this study consists of provincial revenues and district/city revenues in the province which can be formulated as follows:

$$
\begin{aligned}
& \mathrm{RI}_{\mathrm{it}}=\frac{\text { Province Revenue }_{\mathrm{it}}}{\text { Cental }_{\mathrm{t}}+\text { Province Revenue }_{\mathrm{it}}} . \\
& \text { EGit }=\alpha_{0}+\alpha_{1} \text { RIit }+\alpha_{2} \text { Xit }+ \text { Eit . . }
\end{aligned}
$$

b. Expenditure Approach.

The fiscal decentralization indicator of this approach is measured by the provincial spending ratio. Expenditure Indicator (EI) is the ratio of local government expenditure (provincial and district/city) to central and local government expenditures. The expenditures or expenditures of local governments used in this study consist of provincial expenditures and district/cities within the province which can be formulated as follows:

$$
\begin{aligned}
& \mathrm{EI}_{\mathrm{it}}=\frac{\text { Province Expenditure }_{\mathrm{it}}}{\text { Cental }_{\mathrm{t}}+\text { Province Expenditure }_{\mathrm{it}}} \\
& \text { EGit }=\alpha_{0}+\alpha_{1} \text { EIit }+\alpha_{2} \text { Xit }+ \text { eit } \ldots
\end{aligned}
$$




\section{c. Local Own Revenue Approach.}

This indicator shows the level of fiscal autonomy of local governments. Size of regional autonomy would be great if all the financial needs in the region could be self-financed by the local government, although the ratio of revenue and expenditure is small. Thus, the consideration of the degree of regional independence becomes very important in measuring fiscal decentralization. Indicators of local revenue (OR) are measured by the ratio of local government revenue (PAD) to the total revenue of local government that can be formulated as follows:

$$
\begin{aligned}
& \mathrm{RI}_{\mathrm{it}}=\frac{\text { Province Own Revenue }_{\mathrm{it}}}{\text { Total Province Revenue }_{\mathrm{it}}} \ldots . . . \\
& \text { EGit }=\alpha_{0}+\alpha_{1} \text { ORit }+\alpha_{2} \text { Xit }+ \text { eit }
\end{aligned}
$$

\section{Relationship between fiscal decentralization and community welfare}

In an effort to improve the implementation of fiscal decentralization in order to achieve regional independence, the regional government is required to optimize the potential income of the regions. One of the factors that can encourage the increasing degree of regional fiscal decentralization is sourced from local revenue (PAD). Increasing the degree of fiscal decentralization will encourage an increase in the proportion of regional government capital expenditure that is used for the construction of public service facilities and infrastructure so that it will encourage an increase in economic growth and a human development index towards public welfare. Pose, et. Al., (2007) explains, there is a lot of literature which states that fiscal decentralization provides significant changes to welfare and economic benefits.

The main objective of the regional autonomy policy and fiscal decentralization is to accelerate the realization of an increase in the welfare of all people (Bappenas, 2007). Mehmood and Sidiq (2010) state that fiscal decentralization is the basic tool for efficient service delivery. The effectiveness of fiscal decentralization can improve human development and also strengthen the federation. Mehmood and Sidiq's research results show that fiscal decentralization on the expenditure and income side positively correlates with HDI, as well as the urbanization variable which has a positive and significant impact on the HDI. The Gogoi Study (2017) found that there was a fairly positive relationship between fiscal decentralization and human development. The study conducted by Harliyani and Haryadi (2016) found that the ratio of the degree of fiscal decentralization and direct expenditure harmony had a positive and significant effect on the HDI.

The results of other studies, Setyowati and Suparwati (2012) found that PAD proved to have a positive effect on the Human Development Index (HDI) through the allocation of the Capital Expenditure Budget. Jumadi, et.al (2013), there is a positive influence on the ratio of PAD to HDI. Anggarini and Sutaryo (2015), found that the Degree of Decentralization Ratio and Regional Financial Independence Ratio had an effect on the Human Development Index. Putra and Ulupi (2015), found an increase in PAD and DAK in a region would increase the human development index. Sarkoro and Zulfikar (2016) found that regional expenditures and local revenues affect the Human Development Index.

\section{RESEARCH METHODS}

The type of research used in this study is a case study. According to Maxfield (Nazir, 2009), a case study is a study of the status of the subject of research that is pleasing to a specific or typical phase of the overall personality. Research subjects can be 
individuals, groups, institutions, and communities. The purpose of the case study is to provide a detailed description of the background, traits and characteristics that are typical of the case, or the status of the individual, which then from the above characteristics will be made into a general matter.

The data used for this study are panel data in the form of time series from 20102016, and cross section data consisting of 11 districts/cities in Jambi Province, Indonesia. Data is obtained from BPS, Ministry of Finance, and other relevant agencies.

The independent variable is fiscal decentralization measured by the level of fiscal decentralization, which is the ratio of local income to total regional income. The dependent variable of community welfare is measured from the Human Development Index through a three basic dimension approach, namely the dimensions of health, education, and decent life.

This study uses regression analysis with panel data. According to Juanda and Junaidi (2012), the general form of panel data regression (in matrix notation) is as follows:

$$
Y i t=\alpha+\beta \text { Xit }+ \text { uit }
$$

Generally, the data panel application uses a one-way error component model for disturbances by:

$$
u i t=\mu i+v i t
$$

Based on the equation model presented by Juanda and Junaidi (2012), then to analyze the impact of fiscal decentralization on the welfare of the people in Jambi Province, panel data regression analysis using the econometric model approach is as follows:

$$
K M_{i t}=\beta_{0}+\beta_{1} D D F_{i t}+\varepsilon_{i t}
$$

Where:

$\mathrm{KM}=$ Community Welfare is proxied from the HDI

DDF $=$ Degree of Fiscal Decentralization (ratio of local revenue to total regional revenue).

$\beta_{0}=$ coefficient of intercept $/$ constant

$\beta_{1}=$ parameters for control variables

$\mathrm{i}=$ Cross Section (district/city) $\mathrm{i}=1,2, \ldots, 11$

$\mathrm{t}=$ Time Series (time period of study) $\mathrm{t}=1,2, \ldots, 7$

$\varepsilon \quad=$ disturbance term

Panel data regression analysis has three types of models, including Pooled Least Square, Fixed effect, and Random Efect (Gujarati, 2012). To choose one of the models that is appropriate for use in this study, it was first carried out by the chow test and the hausman test. Chow test is done to choose between Pooled Least Square (PLS) or Common Effect approaches with Fixed Effect. Hausman test is done to determine the best and right panel data estimation model between Fixed Effect Model with Random Effect Model. After testing, the research uses the Fixed Effect Model approach.

\section{Hypothesis testing}

Hypothesis testing in this study uses the $t$ test. According to Gujarati (2012), the $t$ test is conducted to see the significance of the influence of independent variables on the dependent variable individually and assume other variables are constant.

\section{RESEARCH RESULT}

\section{Degree of fiscal decentralization}

The successful implementation of fiscal decentralization is reflected in the large capability of local governments in managing regional finances, especially those 
originating from the Locally-generated revenue (PAD). The ratio of PAD to total regional revenue (TPD) is known as the degree of fiscal decentralization. The calculation is done by summing the PAD in one area, then dividing it by the total revenue for the same area. The greater the ratio of PAD, the higher the degree of fiscal decentralization, which means that the financial capacity of the regions derived from own income is higher in the formation of regional income.

Table 4. Degree of district/city fiscal decentralization in Jambi Province

\begin{tabular}{|c|c|c|c|c|c|c|c|c|c|c|}
\hline \multirow{2}{*}{ No. } & \multirow{2}{*}{ Region } & \multicolumn{7}{|c|}{ Ratio of PAD to Regional Income (\%) } & \multirow{2}{*}{$\begin{array}{l}\text { Ave- } \\
\text { rage } \\
(\%)\end{array}$} & \multirow{2}{*}{$\begin{array}{c}\text { Category of } \\
\text { Fiscal } \\
\text { Decentralization }\end{array}$} \\
\hline & & 2010 & 2011 & 2012 & 2013 & 2014 & 2015 & 2016 & & \\
\hline 1 & Kerinci & 3.92 & 5.52 & 4.49 & 7.00 & 7.09 & 7.24 & 5.74 & 5.86 & Very less \\
\hline 2 & Merangin & 6.81 & 5.61 & 3.79 & 4.80 & 5.21 & 7.48 & 6.11 & 5.69 & Very less \\
\hline 3 & Sarolangun & 5.03 & 4.75 & 3.73 & 3.80 & 6.35 & 8.61 & 5.85 & 5.45 & Very less \\
\hline 4 & Batanghari & 3.56 & 5.50 & 4.52 & 5.34 & 7.45 & 4.79 & 7.09 & 5.46 & Very less \\
\hline 5 & Muaro Jambi & 2.79 & 3.95 & 4.31 & 5.07 & 6.20 & 4.74 & 4.82 & 4.55 & Very less \\
\hline 6 & Tanjung Jabung Timur & 2.95 & 3.67 & 3.63 & 3.36 & 3.72 & 4.18 & 3.50 & 3.57 & Very less \\
\hline 7 & Tanjung Jabung Barat & 2.95 & 4.53 & 4.50 & 4.96 & 6.85 & 7.31 & 7.44 & 5.51 & Very less \\
\hline 8 & Tebo & 3.15 & 3.32 & 3.94 & 4.33 & 6.12 & 7.06 & 5.99 & 4.84 & Very less \\
\hline 9 & Bungo & 7.52 & 8.55 & 8.14 & 8.52 & 4.45 & 9.95 & 8.97 & 8.02 & Very less \\
\hline 10 & City of Jambi & 10.46 & 11.30 & 10.43 & 12.80 & 18.67 & 19.03 & 19.81 & 14.64 & Less \\
\hline 11 & City of Sungai Penuh & 1.06 & 3.18 & 4.17 & 4.35 & 5.69 & 5.79 & 5.29 & 4.22 & Very less \\
\hline 12 & Jambi Province & 41.86 & 47.35 & 37.51 & 36.86 & 40.48 & 39.66 & 37.01 & 40.10 & Good \\
\hline
\end{tabular}

Source: BPS, Regional Financial Statistics, 2010 - 2016, processed

Table 4 shows that during the period of 2010-2016 the degree of fiscal decentralization in each district/city in Jambi province is generally very less, since the degree of fiscal decentralization of each district/city ranges from on average 3.57-14.64 percent. The degree of fiscal decentralization for Jambi Province has been categorized either by 40.10 percent.

\section{Community welfare}

Human development is a development paradigm that places humans as the focus and the ultimate goal of all development activities, namely the achievement of mastery over resources, in order to obtain income to achieve decent life, increase health status to increase long and healthy life and improve education (literacy) and skills to be able to participate in society and economic activities. Human development performance as indicated by the HDI is a reflection of the level of community welfare. Increasing the HDI rate means an increase in the level of community welfare.

Table 5. Development index of each regency/city in Jambi Province in 2010 - 2016

\begin{tabular}{clcccccccc}
\hline \multirow{2}{*}{ No. Region } & & \multicolumn{7}{c}{ Human Development Index (HDI) } & Category \\
\cline { 3 - 9 } & & $\mathbf{2 0 1 0}$ & $\mathbf{2 0 1 1}$ & $\mathbf{2 0 1 2}$ & $\mathbf{2 0 1 3}$ & $\mathbf{2 0 1 4}$ & $\mathbf{2 0 1 5}$ & $\mathbf{2 0 1 6}$ & \\
\hline 1 & Kerinci & 65.16 & 65.9 & 66.7 & 67.5 & 67.96 & 68.89 & 69.68 & medium \\
2 & Merangin & 63.85 & 64.4 & 65.3 & 65.8 & 66.21 & 67.4 & 67.86 & medium \\
3 & Sarolangun & 64.64 & 65.2 & 66.2 & 67.1 & 67.67 & 68.1 & 68.73 & medium \\
4 & Batanghari & 65.67 & 66.3 & 67 & 67.2 & 67.68 & 68.05 & 68.7 & medium \\
5 & Muaro Jambi & 62.84 & 63.4 & 64.2 & 65.1 & 65.71 & 66.66 & 67.55 & medium \\
6 & Tanjung Jabung Timur & 57.21 & 57.8 & 58.6 & 59.4 & 59.88 & 61.12 & 61.88 & medium \\
7 & Tanjung Jabung Barat & 61.49 & 62 & 62.9 & 63.5 & 64.04 & 65.03 & 65.91 & medium \\
8 & Tebo & 63.62 & 64.5 & 65.2 & 65.9 & 66.63 & 67.29 & 68.05 & medium \\
9 & Bungo & 66.28 & 66.7 & 67.2 & 67.5 & 67.93 & 68.34 & 68.77 & medium \\
10 & City of Jambi & 72.23 & 73 & 73.8 & 74.2 & 74.86 & 75.58 & 76.14 & medium \\
11 & City of Sungai Penuh & 69.91 & 70.6 & 71.2 & 72.1 & 72.48 & 73.03 & 73.35 & medium \\
\hline $\mathbf{1 2}$ & Jambi Province & $\mathbf{6 5 . 3 9}$ & $\mathbf{6 6 . 1}$ & $\mathbf{6 6 . 9}$ & $\mathbf{6 7 . 8}$ & $\mathbf{6 8 . 2 4}$ & $\mathbf{6 8 . 6 9}$ & $\mathbf{6 9 . 6 2}$ & medium \\
\hline Source: & BPS Jambi Province, HDI year $2010-2016$ & & & & &
\end{tabular}


Based on the category of HDI achievement as defined by criteria by UNDP adopted by BPS (BPS, 2017), ie areas that are included in low HDI (HDI $<60)$, medium $(60 \leq$ $\mathrm{HDI}<70)$, high $(70 \leq \mathrm{HDI}<80$ ), and very high (HDI $\geq 80)$. In general, until $2016 \mathrm{HDI}$ in each district/city including Jambi Province is categorized as medium, except Jambi City (76.14) and Sungai Penuh Municipality (73.35) are categorized as high.

\section{Estimation result of regression model} as in table 6.

Data processing through E-views 8, obtained by estimation of fixed effect model

Table 6. Regression coefficient based on estimation result of fixed effect model

\begin{tabular}{crrrl}
\hline Variable & Coefficient & Std. Error & t-Statistic & Prob. \\
\hline C & 63.90160 & 0.462693 & 138.1080 & 0.0000 \\
DDF? & 0.515004 & 0.078960 & 6.522302 & 0.0000 \\
\hline
\end{tabular}

Source: Processed E-views data 8.

From the panel data regression result, it can be explained as follows:

a. The constant coefficient value is 63.90160. This means that if the DDF (Fiscal Decentralization) is fixed or the value is 0 , then $\mathrm{KM}$ (community welfare) reaches 63.90160.

b. DDF variable coefficient (Fiscal Decentralization)Fiscal decentralization variable regression coefficient of 0.515004 . This means that every increase in the degree of fiscal decentralization by 1 percent, it will increase community welfare by 0.51 percent, assuming other independent variables are fixed.

\section{Coefficients of determination}

This test is used to measure how much variation of the value of the dependent variable, can be explained by independent variables. The coefficient of determination also shows the suitability of the regression line to the data. The commonly used in panel data analysis is Adjusted R-squared.

Table 7. Coefficient of determination based on fixed effect estimation results

\begin{tabular}{lrll}
\hline \hline R-squared & 0.929787 & Mean dependent var & 66.79818 \\
Adjusted R-squared & 0.917905 & S.D. dependent var & 3.976101 \\
S.E. of regression & 1.139242 & Akaike info criterion & 3.240874 \\
Sum squared resid & 84.36175 & Schwarz criterion & 3.606142 \\
Log likelihood & -112.7737 & Hannan-Quinn criter. & 3.386978 \\
F-statistic & 78.25047 & Durbin-Watson stat & 0.727997 \\
Prob(F-statistic) & 0.000000 & & \\
\hline \hline
\end{tabular}

Source: Processed E-views data 8.

Adj Value R-squared $=0.917905$, indicating that variation from independent variable able to explain dependent variable equal to 91.79 percent while the rest equal to 8.21 percent explained other variable not examined (outside model).

\section{Hypothesis testing}

The value of $\mathrm{t}$ table can be seen in table $\mathrm{t}$ statistics at $\mathrm{df}=\mathrm{nk}-1(77-4-1)=72(\mathrm{k}$ is the number of independent variables), obtained results of t table with 2-sided test at significance $\alpha=0.05$ of 1.99346 . The result of tcount (t-statistic) fiscal decentralization variable is 6.522302. Compared with $t$ table, the value of $t$ count $>t$ table $(6.522302>$ $1.99346)$ or probability significance value $<\alpha(0.0000<0.05)$, so that $\mathrm{H} 0$ is rejected and $\mathrm{Ha}$ is accepted. This means that the fiscal decentralization variable has a significant effect 
on the variable public welfare. The results of this study indicate that fiscal decentralization has a positive impact on people's welfare. This means that the higher the degree of fiscal decentralization the higher the level of public welfare.

\section{Discussion}

Based on the estimation results show that fiscal decentralization has a positive and significant impact on the welfare of the district/city communities in Jambi Province. This condition identifies that an increase in fiscal decentralization has an impact on improving people's welfare or it can be said that the higher the degree of fiscal decentralization, the higher the level of welfare of the community. Thus it can be interpreted that during the 2010-2016 observation period proving that fiscal decentralization carried out so far has been able to improve the welfare of the people proxied from the HDI in each district/city in Jambi Province.

The results of this study support the fiscal federalism theory (Oates, 2005) and empirical findings including; Mehmood and Sidiq (2010) show that fiscal decentralization on the expenditure and income side is positively correlated with HDI. The results of the research by Harliyani and Haryadi (2016) found that the ratio of the degree of fiscal decentralization and direct expenditure harmony had a positive and significant effect on the HDI. Anggarini and Sutaryo (2015), found that the Degree of Decentralization Ratio and Regional Financial Independence Ratio had an effect on the Human Development Index, and Jumadi, et.al (2013), there was a positive influence on the ratio of PAD to HDI.

The results of this study reinforce the argument, where one of the objectives of the decentralization and regional autonomy policy is to make the government closer to its people, so that government services can be carried out more efficiently, quickly and effectively. This reasoning is based on the assumption that district and city governments have a better understanding of the needs and aspirations of their communities than the central government (Kuncoro, 2014). For this reason, fiscal decentralization will make the local government more aware of what the community wants and needs.

Todaro and Smith (2012), explained that the government through fiscal decentralization has an important role in providing goods that are not provided by the private sector, such as road and dam infrastructure that will improve the living standards of the population at a reasonable level because fiscal decentralization will improve efficiency based on the ownership of better information about the needs of the population by the regional government compared to the central government and fiscal decentralization will direct the government's development program to local interests that are tailored to the local environment.

\section{CONCLUSIONS AND RECOMMENDATIONS}

\section{Conclusions}

The degree of fiscal decentralization, namely the ratio of district own source revenue (PAD) to total regional income (TPD) in each district/city in Jambi Province is relatively relatively low, whereas for Jambi Province it has been in a good category.

The welfare of the people described by the human development index in each district/city including Jambi Province is still in the moderate category, except Jambi City (76.14) and Kota Sungai Penuh (73.35) are categorized as high.

Fiscal decentralization has a positive and significant impact on improving community welfare. it means that the better the implementation of fiscal decentralization, the higher the level of community welfare. 


\section{Recommendations}

In general, the level of fiscal decentralization of districts/cities in Jambi Province is still relatively very low. For this reason, it is expected that local governments will continue to look for potential sources of regional revenue to be extracted and managed, and reorganize the system of collecting regional taxes and retributions in an integrated manner to avoid leaks and illegal levies.

In addition, in an effort to improve the welfare of the community it is expected that the regional government to prioritize regional development related to the provision of infrastructure, must really touch the joints of people's lives such as education, health and the economy.

\section{BIBLIOGRAPHY}

Akai, Nobuo., and Masayo Sakata. (2002), Fiscal Decentralization Contributes to Economic Growth: Evidence from State-Level Cross-Section Data for the United States. Journal of Urban Economics, LII pp.93-108

Anggarini, T dan Sutaryo. (2015). Pengaruh rasio keuangan pemerintah daerah terhadap indeks pembangunan manusia pemerintah Provinsi di Indonesia. Simposium Nasional Akuntansi 18 Medan 16-19 September 2015.

Bappenas. (2007). Laporan Perkembangan Pencapaian Millennium Development Goals Indonesia 2007, Badan Perencanaan Pembangunan Nasional, Jakarta.

- (2011). Buku Pegangan 2011: Penyelenggaraan Pemerintahan dan Pembangunan Daerah. Jakarta: Bappenas. https://www.bappenas.go.id/ files/handbook-2011.pdf.

Bodman, P., Kelly Ana Heaton and Andrew Hodge. (2009). Fiscal Decentralisation and Economic Growth: A Bayesian Model Averaging Approach. MRG@UQ Discussion Paper, School of Economics, University of Queensland.

BPS, (2016). Indeks Pembangunan Manusia (IPM) tahun 2015. Berita Resmi Statistik. BPS Provinsi Jambi. No. 038/07/15/th. IX, 1 Juli 2016

. 2017. Indeks Pembangunan Manusia (IPM) tahun 2016. Berita Resmi Statistik. BPS Provinsi Jambi. No. 25/05/15/Th.XI, 5 Mei 2017.

Christy, Fhino Andrea dan Priyo Hari Adi. (2009). Hubungan Antara Dana Alokasi Umum, Belanja Modal dan Kualitas Pembangunan Manusia. The 3rd National Conference UKWMS Surabaya.

Fahrudin, Adi. (2012). Pengantar Kesejahteraan Sosial. Bandung: Refika Aditama.

Faridi, Muhammad Zahir. (2011). Contribution of Fiscal Decentralization to Economic Growth: Evidence from Pakistan. Pakistan Journal of Social Sciences (PJSS)Vol. 31, No. 1 (June 2011): 1-13

Gogoi, Anuradha. (2017). A Study on Impact of Fiscal Decentralization on Human Development in India and an Insight into the scenario of fiscal decentralization in Assam compared to India. International Journal of Interdisciplinary and Multidisciplinary Studies (IJIMS), 2017, Vol 4, No.3,524-535.

Gujarati, Damodar. (2012). Econometrics by example. McGraw-Hill, USA

Harahap, R.U. (2011). Pengaruh dana alokasi umum, dana alokasi khusus dan dana bagi hasil terhadap indeks pembangunan manusia pada kabupaten/kota Propinsi Sumatra Utara. Jurnal Riset Akuntansi dan Bisnis Vol.11 No.1. Maret 2011

Harlina, Eka Marisca dan Haryadi. (2016). Pengaruh Kinerja Keuangan Pemerintah Daerah Terhadap Indeks Pembangunan Manusia di Provinsi Jambi. Jurnal Perspektif Pembiayaan dan Pembangunan Daerah, Vol. 3 No. 3: 129-140.

Iimi, Atsushi. (2005). Decentralization and Economic Growth Revisited: an Empirical Note. Journal of Urban Economics. 57.

Juanda, Bambang dan Junaidi. (2012). Ekonometrika Deret Waktu: Teori dan Aplikas. IPB Press. 
Jumadi., M. Pudjiharjo., Ghozali Maski., Moh. Khusaini. (2013). The Impact of Fiscal Decentralization on Local Economic Development in East Java. IOSR Journal Of Humanities and Social Science. Vol. 13, Issue 1, pp 01-07.

Kuncoro, Mudrajad. (2014). Otonomi Daerah Menuju Era Baru Pembangunan Daerah. edisi 3. Jakarta: Erlangga.

Lindaman, Kara and Kurt Thurmaier (2002). Beyond Efficiency and Economy: An Eximination of Basic Needs and Fiscal Decentrlization. Journal of Publik Economics. The University of Chicago, USA

Mehmood, Rashid and Sara Sadiq. (2010). Impact of Fiscal Decentralisation on Human Development: A Case Study of Pakistan. The Pakistan Development Review 49:4 Part II (Winter 2010): 513-530

Mirza, Denni Sulistio. (2012). Pengaruh Kemiskinan, Pertumbuhan Ekonomi, dan Belanja Modal Terhadap Indeks Pembangunan Manusia di Jawa Tengah Tahun 2006-2009. Economics Development Analysis Journal. 1 (1) (2012). http://journal.unnes.ac.id/ sju/index.php/edaj

Nazir, Moh. (2009). Metode Penelitian. Jakarta: Ghalia Indonesia

Oates, Wallace. E. (2005). Toward a Second Generation Theory of Fiscal Federalism. International Tax and Publik Finance, 2. http://dx.doi.org/ 10.1007/s10797-0051619-9.

Pose, et.al. (2007). Fiscal Decentralization, Efficiency and Growth. Department Of Geography and Environmental, London School of Economics. Avaliable: http://www.iza.org

Priambodo, Anugrah dan Noor, Iswan. (2016). Analisis Pengaruh Belanja Pemerintah Daerah Terhadap Indeks Pembangunan Manusia (Studi pada Kabupaten/Kota di Pulau Jawa Tahun 2007-2013). Jurnal Ilmiah FEB Universitas Brawijaya.Vol.3, No.2, 2016

Putra, P.G.M. dan Ulupi, I.G.K.A. (2015). Pendapatan asli daerah, dana alokasi umum, dana alokasi khusus untuk meningkatkan Indeks Pembangunan Manusia. EJurnal Akuntansi Universitas Udayana 11.3: 836-877

Sarkoro, H dan Zulfikar. (2016). Dana alokasi khusus dan pendapatan asli daerah terhadap Indeks Pembangunan Manusia (studi empiris pada pemerintah Provinsi se-Indonesia Tahun 2012-2014). Fakultas Ekonomi dan Bisnis Universitas Muhammadiyah, Surakarta.

Setyowati, Lilis dan Yohana Kus Suparwati. (2012). Pengaruh Pertumbuhan Ekonomi, DAU, DAK, PAD Terhadap Indeks Pembangunan Manusia dengan Pengalokasian Anggaran Belanja Modal Sebagai Variabel Intervening. Pretasi. Juni 2012. Vol.9, No. 1, ISSN 1441-1497.

Slinko, Irina. (2002). Fiscal Decentralization on The Budget Revenue Inequity among Munipacalities and Growth Russian Regions. Avaliable: http://www.econpapers.repec.org.

Soejoto, Ady, Waspodo Tjipto Subroto, \& Suyanto. (2015). Fiscal Decentralization Policy in Promoting Indonesia Human Development. International Journal of Economics and Financial Issues. Vol. 5(3) :763-771.

Soetomo. 2014. Kesejahteraan dan Upaya Mewujudkannya dalam Perspektif Masyarakat Lokal. Yogyakarta: Pustaka Pelajar.

Todaro, Michael P. and Stephen C. Smith. (2006). Economic development ( $9^{\text {th }}$ ed.). Boston: Addison Wesley. . (2012). Economic development (1 $11^{\text {th }}$ ed.). Boston: Addison Wesley. . (2015). Economic development. $12^{\text {th }}$ edition. www.pearsonhighered.com.

UNDP. (1990). Human Development Report 1990. Oxford Universitiy Press. New York. . (2010). Human Development Report 2010. 20th Anniversary Edition. Oxford Universitiy Press. New York. 